\title{
Profil Distribusi dan Klirens Pengkontras CT SCAN AuNP-PAMAM G4- NIMOTUZUMAB disimulasikan menggunakan Senyawa ${ }^{198}$ AuNP-PAMAM G4-NIMOTUZUMAB
}

\section{Distribution and Clearance Profile of AuNP-PAMAM G4-NIMOTUZUMAB Simulated by using ${ }^{198}$ AuNP-PAMAM G4-NIMOTUZUMAB}

\author{
Adang H.G. ${ }^{1}$, Anung Pujiyanto ${ }^{1}$, Abdul Mutalib ${ }^{2}$, Rista A.S ${ }^{2}$, Indrarini L. ${ }^{2}$, Rien R. ${ }^{1}$, Iyus M.Y. ${ }^{2}$, \\ Herlan $\mathbf{S}^{1}$.dan Sutriyo C. ${ }^{3}$ \\ ${ }^{1}$ Pusat Teknologi Radioisotop dan Radiofarmaka BATAN \\ ${ }^{2}$ Universitas Padjadjaran Bandung \\ ${ }^{3}$ Universitas Indonesia \\ Corresponding author : adanghg2014@gmail.com
}

\begin{tabular}{l} 
A R T I C L E IN F O \\
\hline Article history \\
Received date :13 January 2016 \\
Revised date : 11 April 2016 \\
Accepted date :10 June 2016 \\
Available online at: \\
http://kimia.lipi.go.id/inajac/index.php \\
\hline
\end{tabular}

Kata kunci:

CT-Scan, nanopartikel,

Nimotuzumab, distribusi, klirens

Keywords:

CT-Scan, nanoparticle, Nimotuzumab, biodistribution, klirens

\begin{abstract}
Abstrak
Riset nanopartikel emas sebagai senyawa pengkontras CT-Scan telah dimulai sejak 3 tahun lalu di Indonesia. Riset interaksi antibodi monoklonal, khususnya nimotuzumab, dengan reseptor EGFR/HER1 dimulai sejak lima tahun lalu dan telah dimanfaatkan untuk penyiapan senyawa pengkontras MRI (Magnetic Resonance Imaging) spesifik target melalui pelabelan konjugat dendrimer-nimotuzumab dengan radionuklida. Sintesis senyawa AuNP-PAMAM G4-Nimotuzumab untuk diagnosis dan terapi pada kanker paru-paru telah berhasil dilakukan di PTRR dan hasil karakterisasinya dengan menggunakan beberapa metode seperti KCKT (Kromatografi Cair Kinerja Tinggi), SDS (Sodium Dodecyl Sulphate) page elektroforesa dan TEM (Transmission Electron Microscopy) menunjukkan bahwa senyawa yang terbentuk adalah sebagai AuNP-PAMAM G4-Nimotuzumab. Pada penelitian ini telah dilakukan uji pre klinis dari senyawa pengkontras AuNPPAMAM G4-nimotuzumab meliputi uji distribusi dan klirens dengan disimulasikan menggunakan senyawa radioaktiv ${ }^{198}$ AuNP-PAMAM G4nimotuzumab. Hasil uji distribusi senyawa ${ }^{198}$ AuNP-PAMAM G4nimotuzumab menunjukkan penimbunan pada beberapa organ seperti ginjal, hati dan limpa, sedangkan dari hasil uji klirens diperoleh waktu paruh biologis senyawa tersebut adalah 11.77 hari. Hasil pemeriksaan terhadap urin dengan menggunakan kolom PD-10 (Sephadex G25) menunjukkan bahwa $85 \%$ yang dikeluarkan lewat urin masih berbentuk AuNP-PAMAM G4Nimotuzumab. Hasil pencitraan dengan alat autoradiography menunjukkan bahwa sampai dengan 48 jam setelah penyuntikan, akumulasi radioaktivitas yang terdeteksi masih terdapat pada hati.
\end{abstract}

\begin{abstract}
Research on gold nanoparticles as CT-Scan contrast agents has been started 3 years ago in Indonesia. Research on interaction between monoclonal antibodies, particularly nimotuzumab and the receptor EGFR / HERI was initiated five years ago and has been used for the preparation of MRI (Magnetic Resonance Imaging) targeted contrast agent through labeling conjugate of dendrimer-nimotuzumab with gadolinium radionuclides. Synthesis of contrast agent AuNPs-PAMAM G4-nimotuzumab for diagnosis and treatment of lung cancer have been successfully carried out in PTRR and characterization results using several methods such as High Performance Liquid Chromatography (HPLC), Sodium Dodecyl Sulphate (SDS) Page
\end{abstract}


Electrophoresis and Transmission Electron Microscopy (TEM) showed that the compound formed is identified as AuNPs-PAMAM G4-nimotuzumab. In this study preclinical trials of the compound AuNPs-PAMAMG4Nimotuzumab which consist of biodistribution, clearance and autoradiography with simulation using radioactive compounds ${ }^{198} \mathrm{AuNP}$ PAMAM G4-nimotuzumab has been conducted. The biodistribution test results on ${ }^{198}$ AuNP-PAMAM G4-nimotuzumab showed accumulation in some organs such as kidneys, liver and spleen, whereas results of klirens test showed that the biological half-life of the compound was 11.77 days. Urine analysis using PD-10 column (Sephadex G25) showed that $\sim 70 \%$ of the compound excreted was still in the form of AuNP-PAMAM G4-nimotuzumab. Imaging results by means of autoradiography showed that up to 48 hours after injection, radioactivity was still observed in the liver.

(C) 2016 Indonesian Journal of Applied Chemistry. This is an open access article under the CC BY-NC-SA license.

\section{PENDAHULUAN}

Kualitas diagnosis dengan alat CT-Scan sangat ditentukan oleh perbedaan yang tajam antara citra target dengan citra latar-belakang (background) yang dinyatakan sebagai target to background ratio yang tinggi. Peningkatan perbedaan citra ini dapat dilakukan dengan menggunakan senyawa pengkontras yang saat ini kebanyakan di rumah sakit menggunakan senyawa berbasis iodium yang diperoleh melalui import dengan keterbatasan adanya masalah toksisitas dan proses imaging yang hanya sampai ditingkat anatomi, tidak sampai di tingkat molekuler atau seluler ${ }^{[1-2]}$.

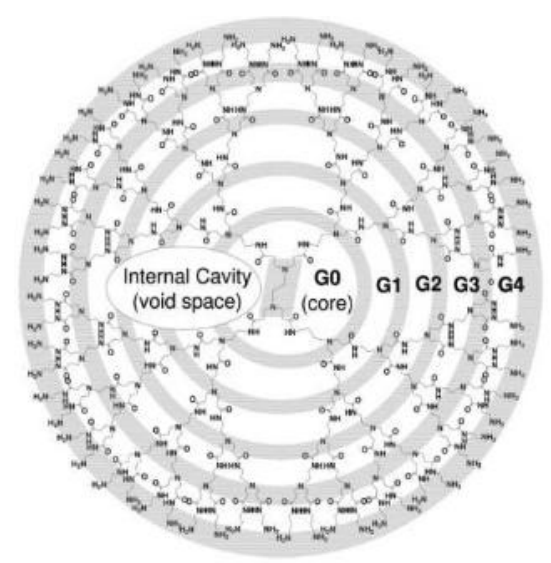

Gambar 1. Struktur lengkap PAMAM G4 dendrimer ${ }^{[1]}$

Dendrimer merupakan polimer bercabang yang berstruktur unik tiga dimensi, memiliki gugus-gugus fungsi yang dapat dimodifikasi pada permukaannya dan dapat membawa bahan aktif secara selektif langsung ke sasaran dan tidak menyebar ke organ/jaringan lain yang tidak diinginkan. Dendrimer poliamidoamin (PAMAM) (Gambar 1) adalah salah satu dendrimer dengan inti etilendiamin yang aman, non-imunogenik, sitotoksisitas minimum, berukuran 1-100 nm, monodispers, dan memiliki rongga internal yang mampu menjerap obat kedalamnya. Sifat unik yang dimiliki oleh dendrimer PAMAM ini mendorong penggunaannya secara luas dalam biomedikasi, terutama dalam hal penghantaran obat, terapi gen, terapi tumor, kemoterapi, dan diagnostik. Pengkonjugasian dendrimer dapat dilakukan dengan molekul pembawa yang spesifik ke target seperti peptida, asam folat, dan antibodi monoclonal ${ }^{[3-5]}$.
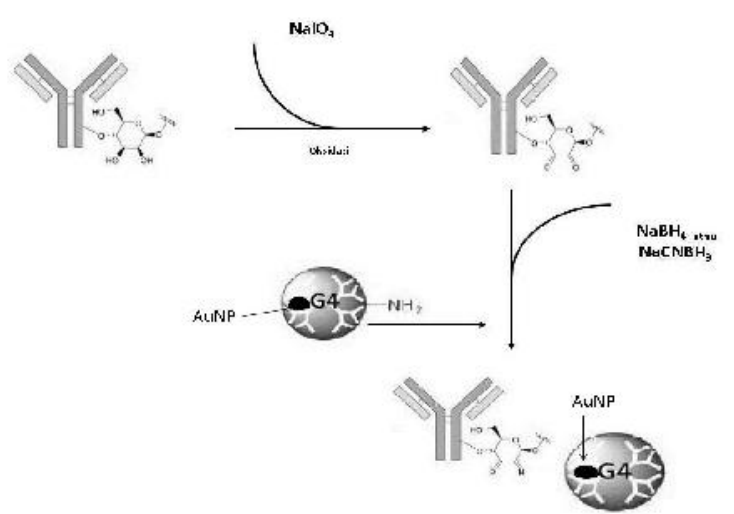

38 | "Profil Distribusi dan Klirens Pengkontras ...": Adang H.G., A. Pujiyanto, A. Mutalib, Rista A.S., Indrarini L., Rien R., Iyus M.Y., Herland S., dan Sutriyo, C. 
Gambar 2. Reaksi konyugasi AuNP-PAMAM G4 dengan Nimotuzumab (Hermanson, $G$. $T$., telah diolah kembali) ${ }^{[2]}$

Riset nanopartikel emas sebagai senyawa pengkontras CT-Scan maupun sebagai radiofarmaka terapi dan nanodevice brachytherapy kanker, telah dimulai sejak 3 tahun lalu di dalam negeri ${ }^{[6-9]}$. Riset interaksi antibodi monoklonal, khususnya nimotuzumab, dengan reseptor EGFR/HER1 yang diekspresikan beberapa jenis sel kanker, telah dimulai sejak lima tahun lalu dan telah dimanfaatkan untuk penyiapan radiofarmaka spesifik target melalui pelabelan konjugat dendrimer-nimotuzumab dengan radionuklida maupun senyawa komplek gadolinium sebagai senyawa pengkontras terarah untuk MRI (Magnetic Resonance Imaging) ${ }^{[10-13]}$. Sintesis senyawa AuNP-PAMAM G4-Nimotuzumab yang diharapkan akan dapat digunakan untuk diagnosis dan terapi pada kanker paru-paru telah berhasil dilakukan di PTRR dan hasil karakterisasinya dengan menggunakan beberapa metode seperti KCKT, SDS page elektroforesa dan TEM menunjukkan bahwa senyawa yang terbentuk adalah benar sebagai AuNP-PAMAM G4-Nimotuzumab ${ }^{[2]}$.

Obat pada umumnya setelah diabsorpsi akan tersebar melalui sirkulasi darah ke seluruh tubuh dan didistribusikan melalui membran tubuh dengan cara yang relatif lebih mudah dan lebih cepat dibanding dengan eliminasi dan ekskresinya. Distribusi adalah proses suatu obat yang secara revesibel meninggalkan aliran darah dan masuk ke cairan ekstra sel dan/atau ke sel-sel jaringan. Uji distribusi pada hewan percobaan merupakan salah satu pengujian yang perlu dilakukan untuk mengetahui pola penyebaran dalam tubuh dari suatu sediaan setelah pemberian (oral, intramuscular, intravena, dsb.), waktu yang diperlukan untuk lokalisasi pada organ yang diharapkan, pelepasan dari organ tubuh, ekskresi dan dapat pula dipakai untuk menentukan waktu paruh biologis sediaan tersebut pada setiap organ. Untuk memperoleh citra hasil uji distribusi dalam bentuk visual, dilakukan pula uji autoradiografi dengan menggunakan hewan tikus. Uji clearence dimaksudkan melihat kecendrungan ekskresi dari radiofarmaka apakah melalui urine atau feses dan seberapa lama atau seberapa cepat radiofarmaka dapat diekskresikan keluar tubuh tikus ${ }^{[1,14-15]}$.

Pada penelitian ini akan dilakukan uji pre klinis dari senyawa pengkontras AuNPPAMAM G4-nimotuzumab yang meliputi uji distribusi, klirens ${ }^{[14]}$ dan uji autoradiografi. Karena senyawa AuNP-PAMAM G4nimotuzumab bukan senyawa radioaktiv maka untuk keperluan pengujian dilakukan simulasi dengan senyawa radioaktiv ${ }^{198}$ AuNP-PAMAM G4-nimotuzumab menggunakan hewan mencit (mus musculus), tikus(rattusnorvegicus), dan kelinci (oryctolagus cuniculus).

\section{METODOLOGI}

\subsection{Bahan}

Nimotuzumab (TheraCIM), larutan Dendrimer PAMAM Generasi $410 \%$ dalam metanol (Sigma-Aldrich), $\mathrm{NaIO}_{4}$ (E.Merck), etilenglikol (E.Merck), ammonium Asetat (E.Merck), asam asetat glasial (E.Merck), asam asetat (E.Merck), $\mathrm{NaH}_{2} \mathrm{PO}_{4}$ (E.Merck), aqua bidestilata steril (PT. IKA, Indonesia), $\mathrm{NaBH}_{4}$ (Fluka), $\mathrm{CuSO}_{4}$ (E.Merck), $\mathrm{NaOH}$ (E.Merck), ammonium bikarbonat (E.Merck), Bovine Serum Albumin (Sigma Aldrich).

\subsection{Alat}

Alat dan bahan yang digunakan dalam penelitian ini diantaranya adalah sentrifus (Hettich EBA 8S), pengaduk (Vortex VWR), $\mathrm{pH}$ meter (Seveneasy Mettler Toledo), timbangan analitik (Denver Instrument), mikropipet (Thermo Electron Corporation dan (Biohit Proline), protein filter. (Vivaspin 30 KDalton molecular weight cut off/ $30 \mathrm{KD}$ MWCO), aluminium foil, syringe, syringe filter, dan alat-alat gelas lainnya yang umum digunakan di labotatorium, spektrofotometer UV/Vis (Jasco, V-550), Autoradiography (Perkin Elmer).

\subsection{Penyediaan AuNP-PAMAM G4- Nimotuzumab.}


AuNP-PAMAM G4-Nimotuzumab dibuat oleh PTRR - BATAN dengan mereaksikan AuNP-PAMAM G4 dengan bentuk aldehid dari Nimotuzumab (CHO-Nimotuzumab). Aktivasi Nimotuzumab menjadi CHO-Nimotuzumab dilakukan dengan mereaksikan Nimotuzumab dengan larutan $\mathrm{NaIO}_{4}$. Prosedur yang sama juga digunakan untuk penyiapan ${ }^{198}$ AuNP-PAMAM G4 dengan Nimotuzumab.

\subsection{Pemurnian Konjugat ${ }^{198} \mathrm{AuNP}(\mathrm{AuNP})-$ Dendrimer PAMAM G4 -Nimotuzumab}

Pemurnian konjugat dilakukan dengan menggunakan metode ultrafiltrasi sentrifugasi menggunakan protein filter (Vivaspin $30 \mathrm{KD}$ MWCO). Ultrafiltrasi dilakukan dengan cara memipet $1 \mathrm{~mL}$ larutan konjugat dan dimasukkan kedalam protein filter yang dikuti dengan penambahan dapar fosfat $\mathrm{pH} \quad 6,5$ sehingga volume nya menjadi $2 \mathrm{~mL}$. Protein filter kemudian disentrifugasi selama 15 menit dengan kecepatan 4000 rpm sehingga diperoleh volume akhir $150 \mu \mathrm{L}$. Sentrifugasi dilakukan 4 kali yang diikuti dengan pengambilan kembali konjugat dendrimer PAMAM G4Nimotuzumab hasil pemurnian. Produk yang diperoleh volumenya dicukupkan sampai $1 \mathrm{~mL}$ dan selanjutnya dianalisis dengan spektrofotometer UV.

\subsection{Uji Distribusi \\ ${ }^{198}$ AuNP(AuNP)-PAMAM Nimotuzumab.}

Konyugat

G4-

Hewan coba mencit normal diinjeksi secara intravena dengan sediaan ${ }^{198}$ AuNPPAMAM G4-nimotuzumab radioaktivitas \pm 20 $\mu \mathrm{Ci}$, volume maksimum $100 \mu \mathrm{L}$ yang mengandung $3,45 \times 10^{-8}$ atau $1,77 \times 10^{-6}$ mol/injeksi. Hewan coba mencit setelah injeksi ${ }^{198}$ AuNP-PAMAM G4-nimotuzumab pada selang waktu yang telah ditentukan kemudian dibunuh. Setiap hewan akan melalui proses pengambilan darah dari jantung (cardiac puncture) sebelum proses pembedahan, kemudian organ lain yang diambil adalah kandung kemih, ginjal, usus, lambung, hati, jantung, paru, limpa, tulang, otot dan otak.
Organ yang diambil dicacah untuk mengetahui tangkapan ${ }^{198}$ AuNP-PAMAM G4-nimotuzumab di masing-masing organ. Selesai perlakuan tersebut bangkai hewan coba disimpan dalam refrigerator hingga radioradioaktivitasnya meluruh, kemudian dilimbahkan.

\subsection{Uji Klirens Konyugat ${ }^{198} A u N P(A u N P)-$ PAMAM G4 -Nimotuzumab}

Hewan coba tikus normal diinjeksi dengan sediaan ${ }^{198}$ AuNP-PAMAM G4-nimotuzumab secara intravena dengan radioaktivitas $\pm 40 \mu \mathrm{Ci}$ dalam volume maksimum $200 \mu \mathrm{L}$. Hewan coba tikus setelah injeksi ${ }^{198}$ AuNP-PAMAM G4nimotuzumab ditempatkan pada metabolic cage kemudian urin dan feses ditampung secara terpisah. Setiap 24 jam urine dan feses yang ditampung kemudian dicacah. Penampungan urine dan feces dilakukan sampai dengan 144 jam setelah penyuntikan.

\subsection{Uji Autoradiografi Konyugat ${ }^{198}$ AuNP(AuNP)-PAMAM Nimotuzumab \\ G4}

Hewan coba tikus normal diinjeksi dengan sediaan ${ }^{198}$ AuNP-PAMAM G4-nimotuzumab secara intravena dengan dengan radioaktivitas $\pm 40 \mu \mathrm{Ci}$ dan volume $100 \mu \mathrm{L}$. Hewan coba mencit setelah injeksi ${ }^{198}$ AuNP-PAMAM G4nimotuzumab 3 jam dan 24 jam dibunuh dengan metode euthanasia. Bangkainya disimpan dalam freezer $-22^{\circ} \mathrm{C}$ selama 24 jam, kemudian setelah 24 jam bangkai tersebut di slices menggunakan mikrotom dan discan dengan alat autoradiografi.

\section{HASIL DAN PEMBAHASAN}

Penggunaan senyawa radioaktiv ${ }^{198}$ AuNP-PAMAM G4-Nimotuzumab dalam uji distribusi dan clearance sebagai pengganti senyawa AuNP-PAMAM G4-Nimotuzumab dimaksudkan untuk memudahkan melihat keberadaan senyawa tersebut dalam tubuh hewan uji menggunakan alat pendeteksi radioaktiv seperti Gamma Ionization Chamber (GIC) ataupun dengan Dose calibrator. 
Sebelum dilakukan pengujian distribusi, klirens dan autoradiografi, ditentukan senyawa ${ }^{198}$ AuNPs-PAMAM G4-Nimotuzumab setelah pemurnian.

Hasil penentuan rendemen setelah pemurnian senyawa ${ }^{198}$ AuNP-PAMAM G4Nimotuzumab menggunakan penyaring protein Vivaspin $30 \mathrm{KD}$ MWCO dapat dilihat pada Gambar 3. Dari Gambar 3 terlihat bahwa \% rendemen adalah $91.11 \%$ dan yang lolos ke filtrat hanya $0.04 \%$.

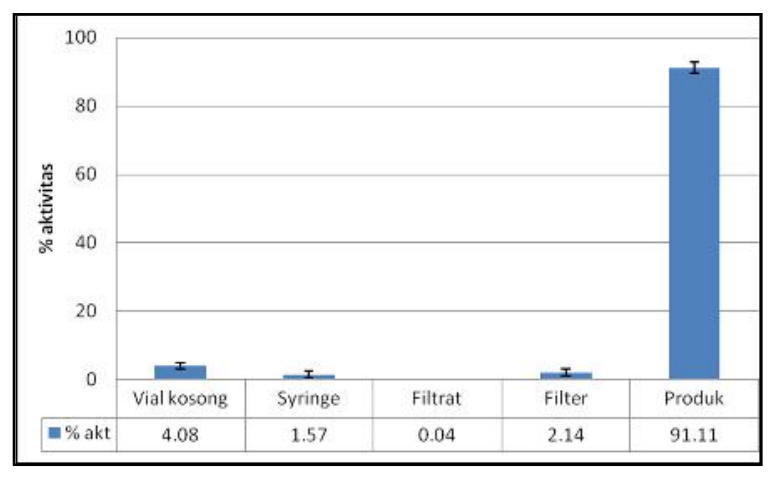

Gambar 3. Perhitungan rendemen ${ }^{198} \mathrm{AuNP}-$ PAMAM G4-Nimotuzumab

Hal ini menunjukkan bahwa pada filtrat tidak terdapat pecahan dari senyawa ${ }^{198} \mathrm{AuNP}$ PAMAM G4-Nimotuzumab seperti misalnya ${ }^{198} \mathrm{Au}$ atau ${ }^{198} \mathrm{AuNP}-\mathrm{PAMAM}$ G4 yang mestinya lolos ke filtrat karena berat molekulnya $<30 \mathrm{KD}$. Dari hasil penelusuran radioaktivitas juga dapat diketahui bahwa sejumlah $8.89 \%$ radioaktivitas yang hilang terdapat pada vial kosong, syringe, filtrat dan filter.

Persetujuan penggunaan hewan untuk melakukan uji distribusi dan clearance terhadap senyawa ${ }^{198}$ AuNP-PAMAM G4-Nimotuzumab diperoleh dari Komite Etik Hewan Badan Tenaga Nuklir Nasional dengan nomor surat 001/KEPPHP-BATAN/III/2015

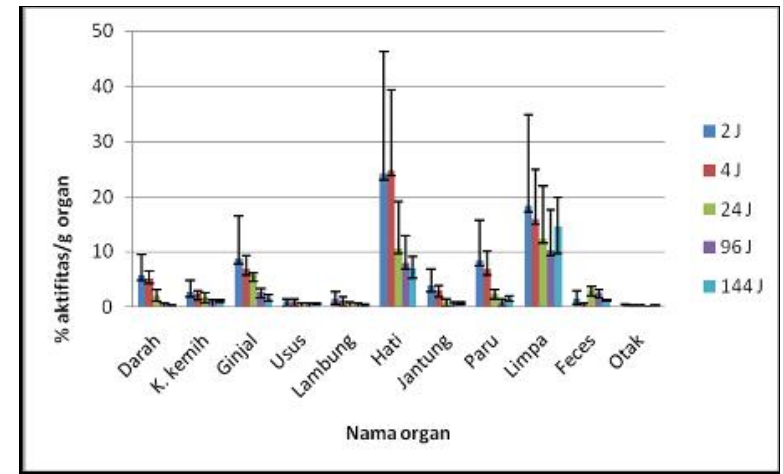

Gambar 4. Hasil uji distribusi ${ }^{198}$ AuNP-PAMAM G4-Nimotuzumab pada hewan mencit (\% radioaktivitas/gram organ) ${ }^{198}$ AuNP-PAMAM G4Nimotuzumab setelah lewat Vivaspin $30 \mathrm{KD}$ MWCO. \% senyawa tersebut masih berada dalam tubuh.

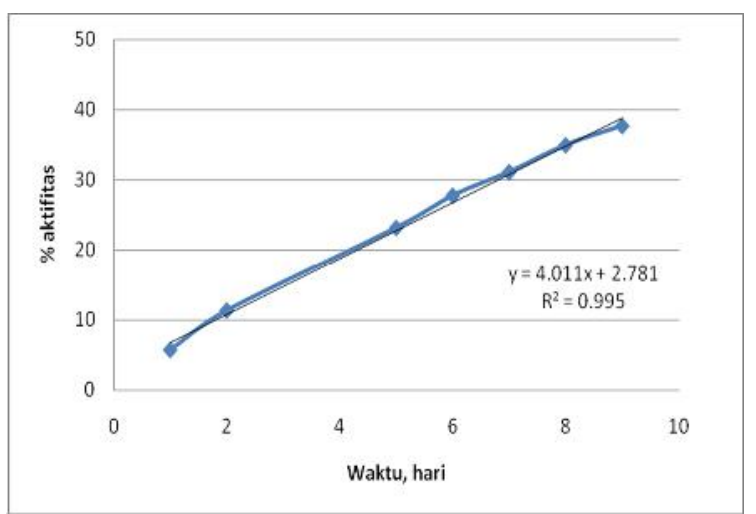

Gambar 5. Profil total klirens(urin + feces) senyawa kontras ${ }^{198}$ AuNP-PAMAM G4-Nimotuzumab pada tikus putih

Dari profil total klirens (urin + feces) yang ditampilkan pada Gambar 7, terlihat bahwa sampai dengan hari ke 9 setelah penyuntikan sekitar $38 \%$ dari senyawa AuNPPAMAM G4-Nimotuzumab telah diekskresikan melalui urin dan feces, sehingga dari kromatogram tersebut dapat dihitung waktu paruh biologis sediaan menggunakan rumus perhitungan sebagai berikut :

$Y=4.011 x+2.781$

$47.219=4.011 X$

$X=11.7724$

Waktu paruh biologis (t1/2 biologis) AuNPPAMAM G4-Nimotuzumab $=11.7724$ hari 


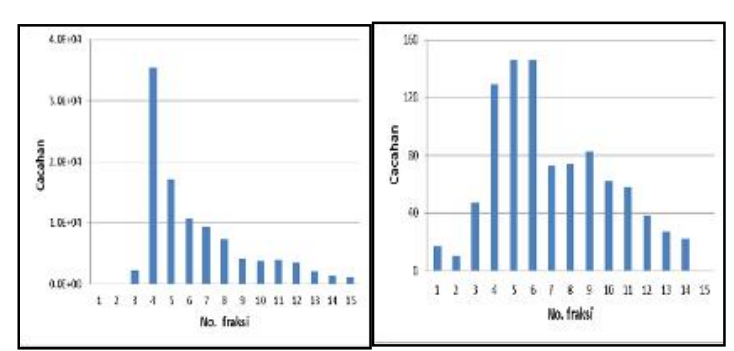

A

B

Gambar 6. Profil elusi kolom PD10 (Sephadex G25) dari (A) Senyawa ${ }^{198}$ AuNPPAMAM G4-Nimotuzumab asal; (B) Urin dari tikus putih setelah disuntik dengan ${ }^{198}$ AuNP-PAMAM G4Nimotuzumab

Profil elusi dari kolom PD10 dari senyawa ${ }^{198}$ AuNP-PAMAM G4-Nimotuzumab sebelum disuntikkan ke tikus (A) dan profil elusi kolom PD10 dari hasil ekskresi urin setelah mencit disuntik sediaan ${ }^{198} \mathrm{AuNP}$ PAMAM G4-Nimotuzumab (B) dapat dilihat pada Gambar 8. Bila dilihat dari kromatogram Gambar 8, hasil ekskresi urin sebagian besar $(\sim 70 \%$ dari asal $85 \%)$ masih berupa senyawa ${ }^{198}$ AuNP-PAMAM G4-Nimotuzumab yang artinya sebagian besar senyawa diekskresikan masih utuh sebagai ${ }^{198}$ AuNP-PAMAM G4Nimotuzumab tidak mengalami kerusakan atau peruraian selama proses metabolisme, distribusi sampai ekskresi.

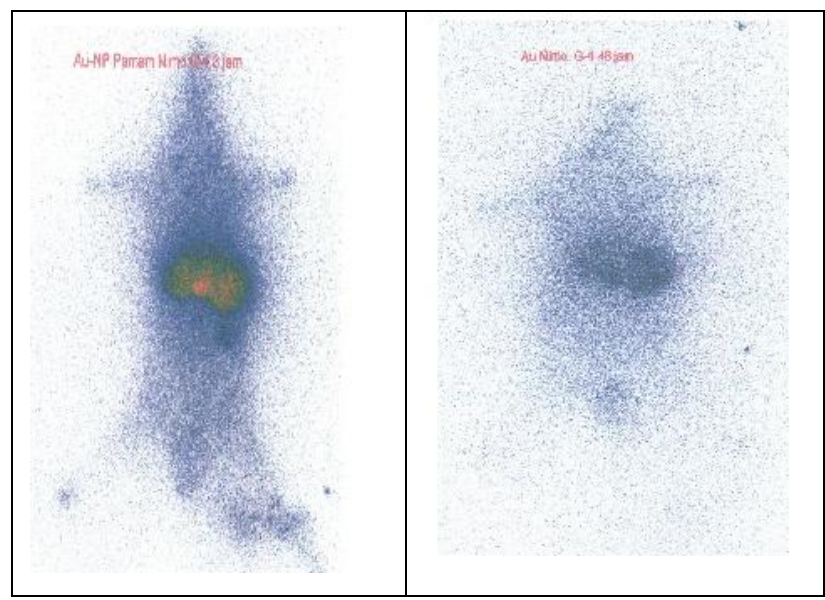

Gambar 7. Hasil Pengujian autography mencit setelah disuntik 3 jam dan 48 jam dengan ${ }^{198}$ AuNP-PAMAM G4Nimotuzumab

\section{Accreditation number : 540/AU1/P2MI LIPI/06/2013}

Hasil pencitraan terhadap mencit yang sudah disuntik $k_{B}$ dengan senyawa ${ }^{198} \mathrm{AuNP}$ PAMAM G4-Nimotuzumab (3 jam dan 48 jam setelah penyuntikan) ditunjukkan pada Gambar 9. Hasil pencitraan dengan menggunakan alat autoradiografi, baik pada 3 jam ataupun 48 jam setelah penyuntikan memperlihatkan akumulasi radioaktivitas masih terdapat pada hati. Hasil pencitraan ini memperkuat data distribusi (Gambar 4) yaitu dari 2 jam sampai 144 jam setelah penyuntikan, akumulasi di hati dan limpa terdeteksi tinggi. Akibat dari akumulasi yang tinggi pada organ hati dan limpa, menyebabkan klirens yang melewati feces akan meningkat dan hal ini terbukti dari lebih tingginya akumulasi ekskresi lewat feces dari pada urin dalam rentang waktu 144 jam setelah penyuntikan.

\section{KESIMPULAN}

Melalui simulasi menggunakan ${ }^{198} \mathrm{AuNP}$ PAMAM G4-Nimotuzumab disimpulkan bahwa profil distribusi senyawa AuNP-PAMAM G4Nimotuzumab menunjukkan akumulasi terjadi pada beberapa organ yaitu ginjal, hati dan limpa. Hingga hari ke 9 setelah penyuntikan sediaan AuNP-PAMAM G4-Nimotuzumab telah diekskresikan melalui urin dan feces sebesar $38 \%$ dan waktu paruh biologisnya 11.7724 hari. Sebagian besar senyawa AuNPPAMAM G4-Nimotuzumab diekskrersikan melalui urin dalam bentuk utuh tidak mengalami penguraian.

\section{DAFTAR PUSTAKA}

[1] Adang H.G., Anung P., Maskur, Herlan S., Rien R., Karakterisasi senyawa pengkontrasCT-Scan terarah AuNPPAMAM G4-Nimotuzumab melalui simulasi menggunakan ${ }^{198}$ AuNPPAMAM G4-Nimotuzumab, hal. 1-6, Jurnal Sains Materi Indonesia, Vo.16, No.1, Oktober 2014.

[2] Takalkar PP., Deshmukh VN, Sakarkar DM, Dendrimer: A Novel Polymer for Drug Delivery System, International Journal for Pharmaceutical Research

42 | "Profil Distribusi dan Klirens Pengkontras ...": Adang H.G., A. Pujiyanto, A. Mutalib, Rista A.S., Indrarini L., Rien R., Iyus M.Y., Herland S., dan Sutriyo, C. 
Scholars (IJPRS), V-3, I-2, 2014, pp.733744

[3] Kangan Li, Shihui Wen, Andrew C Larson, Mingwu Shen, Zhuoli Zhang, Qian Chen, Xiangyang Shi, Guixiang Zhang, Multifunctional dendrimerbased nanoparticles for in vivo MR/CT dual-modal molecular imaging of breast cancer, International Journal of Nanomedicine 2013:8 2589-2600.

[4] Peng C, Zheng L, Chen Q, et al. PEGylated dendrimer-entrapped gold nanoparticles for in vivo blood pool and tumor imaging by computed tomography. Biomaterials, 2012 : 33(4) : 1107-1119.

[5] Wen S, Li K, Cai $\mathrm{H}$, et al. Multifunctional dendrimer-entrapped gold nanoparticles for dual mode CT/MR imaging applications. Biomaterials. 2013;34(5):1570-1580.

[6] Reuveni T., Motiei M., Roman Z., Popovtzer A., Popoptzer R., Multifunctional dendrimer-based nanoparticles for in vivo MR/CT dualmodal molecular imaging of breast cancer, International Journal of Nanomedicine, 8, 2013, 2589-2600.

[7] Kaichuang Ye, Jinbao Qin, Zhiyou Peng, Xinrui Yang, Lijia Huang, Fukang Yuan, Chen Peng, Mier Jiang and Xinwu Lu, Polyethylene glycol- modified dendrimerentrapped gold nanoparticles enhance CT imaging of blood pool in atherosclerotic mice, Nanoscale Research Letters 2014, 9:529

[8] Michael A Firer and Gary Gellerman, Targeted drug delivery for cancer therapy: the other side of antibodies, Journal of Hematology \& Oncology 2012, 5:70.

[9] Tobi Reuveni, Menachem Motiei, Zimam Romman, Aron Popovtzer, Rachela Popovtzer, Targeted gold nanoparticles enable molecular CT imaging of cancer: an in vivo study, International Journal of Nanomedicine 2011:6 2859-2864.

[10] Vinod Prabhu, Siddik Uzzaman, Viswanathan Mariammal Berlin Grace, Chandrasekharan Guruvayoo-rappan
Nanoparticles in Drug Delivery and Cancer Therapy: The Giant Rats Tail, Journal of Cancer Therapy, 2011, 2, 325-334.

[11] Sean L. Kitson, Vincenzo Cuccurullo, Thomas S. Moody and Luigi Mansi, Radionuclide antibody-conjugates, a targeted therapy towards cancer, Current Radiopharmaceuticals, 2013, 6(2), 57-71

[12] Martalena Ramli1, Basuki Hidayat, Cecep Taufik Rustendi et.al., In Vitro and In Vivo Testing of ${ }^{177} \mathrm{Lu}-\quad$ DOTANimotuzumab, a Potential Radioimmunotherapeutical Agent of Cancers, ITB J. Sci., Vol. 44 A, No. 4, 2012, 333-345.

[13] Huanying Zhao, Wei Gu, Ling Ye, Hui Yang, Biodistribution of PAMAM dendrimer conjugated magnetic nanoparticles in mice, $J$ Mater Sci: Mater Med (2014) 25:769-776

[14] Tapan K. Nayak, Kayhan Garmestani, Kwamena E. Baidoo, Diane E. Milenic, and Martin W.Brechbiel, Preparation, biological evaluation and pharmacokinetics of human antiHER1 monoclonal antibody, Panitumumab, labeled with ${ }^{86} \mathrm{Y}$ for quantitative PET imaging of carcinoma, J Nucl Med. 2010 ; 51(6): 942-950.

[15] Ana Christina Opina, Karen J Wong, Gary L Griffiths, Baris I Turkbey, Marcelino Bernardo, Takahito Nakajima, Hisataka Kobayashi, Peter L Choyke \& Olga Vasalatiy, Preparation and long-term biodistribution studies of a PAMAM dendrimer G5-GdBnDOTA conjugate for lymphatic imaging, Nanomedicine (Lond.) (2015) 10(9), 1423-1437.

\footnotetext{
“Profil Distribusi dan Klirens Pengkontras ...": Adang H.G., A. Pujiyanto, A. Mutalib, Rista A.S., 43 Indrarini L., Rien R., Iyus M.Y., Herland S., dan Sutriyo, C.
} 
J.Kim.Terap.Indones., 18(1),

pp. 37-43, June 2016
p-ISSN: 0853-2788, e-ISSN: 2527-7669

Accreditation number : 540/AU1/P2MI LIPI/06/2013

Halaman ini sengaja dikosongkan

This page intentionally left blank 